\title{
THE EFFECT OF CORPORATE IMAGE AND ADVERTISING ON HASANAH CARD ON CUSTOMER'S DECISION TO BECOME A CARD HOLDER IN BNI SYARIAH
}

Raka Agritama Kuncoro

Rakaagritama57@gmail.com

\author{
Sylvia Rozza \\ Sylvia_rozza@yahoo.com \\ Nurul Hasanah \\ Hasanah.nurul12@gmail.com
}

\author{
Sharia Finance and Banking Study Program Politeknik Negeri Jakarta
}

\begin{abstract}
This research aims to analyze the effect of corporate image and advertising on the customer's decision to become a card holder of Hasanah Card in BNI Syariah Bank. The method used in this research is quantitative. The sample is BNI Syariah Customers, with a total of 100 respondents. The results of the research through multiple linear regression tests show that corporate image and advertising have a positive and significant effect either partially or simultaneously on customer decision in using Hasanah Card. The result of the research is expected to be useful as an additional reference for BNI Syariah Bank in making a strategy to increase Hasanah Card users.
\end{abstract}

Keywords: Corporate Image, Advertising, Customer Decisions.

\begin{abstract}
ABSTRAK
Penelitian ini bertujuan untuk menganalisis adakah pengaruh citra perusahaan dan periklanan terhadap keputusan nasabah untuk menjadi card holder Hasanah Card di Bank BNI Syariah. Metode yang digunakan dalam penelitian ini adalah kuantitatif. Sampel dalam penelitian ini adalah Nasabah Bank BNI Syariah, dengan total responden sebanyak 100 orang. Hasil penelitian melalui uji regresi linear berganda menunjukan bahwa citra perusahaan dan periklanan memiliki hubungan yang positif dan signifikan baik secara parsial ataupun secara simultan. Penelitian ini diharapkan dapat bermanfaat sebagai referensi tambahan dalam menyusun strategi untuk meningkatkan jumlah pengguna Hasanah Card di Bank BNI Syariah.
\end{abstract}

Kata Kunci: Citra Perusahaan, Periklanan, Keputuasn Nasabah

\section{INTRODUCTION}

\section{Research Background}

A bank is a financial institution whose job is to collect funds from parties who have excess funds and channel them back in the form of loans to those who are underfunded with the aim of improving the lives of many people and serves to facilitate payment traffic. So far, banking financial institutions in Indonesia manage their finances with a conventional interest-based system, even though Indonesia is a Muslim-majority country that should manage its finances with a sharia system, but public trust still relies on banking financial institutions with conventional systems .

So far, Indonesia only knows banks with conventional systems, until finally in 1991 stood the first Islamic bank namely Bank Muamalat Indonesia which began fully operational a year later in 1992. With the existence of Bank Muamalat Indonesia which implemented the sharia system in its banking activities, encouraged the government to make a regulation that conventional commercial banks can implement the sharia system through the opening of Sharia Business Units. One of the conventional banks that implement the sharia system is Bank BNI, on April 20, 2000 Bank BNI opened a Sharia Business Unit (UUS) with 5 branch offices namely in Malang, Pekalongan, Yogyakarta, Banjarmasin and Jepara, then on June 19 2010 Bank BNI Syariah has changed its status from a Sharia Business Unit to a Sharia Commercial Bank. This change was encouraged by the issuance of Law No. 21/2008 which regulates the authority of fatwas and sharia banking committees, sharia supervision and supervision, selection of sharia supervisory boards (DPS), tax issues, resolution of banking 
disputes, and conversion of sharia business units (UUS ) to be a sharia commercial bank (BUS).

The change of BNI Syariah from UUS to BUS has encouraged increasingly complex products and services offered. BNI Syariah has several products, one of them is the Hasanah Card. Hasanah Card is a sharia credit card. Hasanah Card has 3 types of cards namely Classic, Gold and Platinum. According to Wijayanti (2018), in the Millennial era as it is today, everyone is very easily bored with goods that have been purchased and always easily attracted to new items, and making non-cash payments to feel faster and instant is also a habit that has been happening at this time. Therefore, every person is required to be able to do all their activities more effectively and efficiently, such as doing transactions to buy an item or a product that is desired. In these transactions, it will be more effective and efficient if it done with non-cash tools such as credit cards compared to cash. If seen from the needs of the public for everything that wants fast and instant and is more fond of conducting noncash transactions, BNI Syariah has a great opportunity to offer this Hasanah Card product.

The potential for the development of sharia-based products such as the Hasanah Card in Indonesia has a huge opportunity because the majority of Indonesia's population is Muslim, and the potential of the Muslim population in Indonesia should be an opportunity for Islamic banking institutions, especially BNI Syariah. This opportunity is also supported by several factors, one of which is BNI Syariah has several awards including in 2013 receiving the Silver Brand Champion of the Most Popular Brand 2013, and in 2014 the Digital Brand of the Sharia Commercial Bank and many other awards that can enhance the company's image and opportunities in marketing products from BNI Syariah itself (www.bnisyariah.co.id).

BNI Syariah in marketing Hasanah Card products has carried out several promotional activities through print media such as brochures and through electronic media by making promotional videos of product introductions at one of the third social media sites most frequently visited by everyone including Millennials, YouTube. Promotional activities in the video have been watched more than 162 thousand times (Alexa Internet.Inc). BNI Syariah's awards and promotions that have been carried out should be able to encourage Hasanah Card marketing and sales. But in its implementation, Hasanah Card marketing activities still have obstacles including many competitors from other banks that provide similar financing cards from Islamic banks or conventional banks.

The data obtained from the Consumer Funding Division (CFD) of BNI Syariah Center (2013-2015 period), where for 3 consecutive years BNI Syariah experienced a significant decrease in the number of Hasanah Card holders. For more details, see Table 1 below:

\section{Table 1 Number of Card Holders}

\begin{tabular}{|c|c|c|}
\hline Period & $\begin{array}{c}\text { Hasanah } \\
\text { Card } \\
\text { Customer }\end{array}$ & $\begin{array}{c}\text { Convention } \\
\text { Credit } \\
\text { Card } \\
\text { Customer }\end{array}$ \\
\hline 2013 & 45.686 & 15.091 .684 \\
\hline 2014 & 18.129 & 16.043 .347 \\
\hline 2015 & 16.738 & 16.863 .843 \\
\hline
\end{tabular}

Source: Data processed by CFD BNI Syariah Center and Bank Indonesia Statistics 2013-2015.

From Table 1 it can be seen that there are more and more conventional credit card users compared to sharia credit card users each year, which continue to decline, even though the majority of Indonesian people are Muslims. Therefore, it is important to examine what factors effect the customer's decision to use Hasanah Card in their transaction activities both in terms of corporate image and advertising. Based on the facts above, the author is interested in conducting research, in the form of a study entitled: "The Effect of Corporate Image and Advertising on Hasanah Card on the Customer Decision to become a Card Holder at BNI Syariah" 


\section{Research Problem Formulation}

The majority of Indonesian people are Muslims who prefer products from conventional banks that use the interest system compared to products from Islamic banks that are in accordance with Islamic principles. The corporate image is excellent and it has already implemented expensive advertising.

1. Hasanah Card users continue to decline.

2.. $\quad$ Research that discusses the effect of corporate image and advertising on the decision to become a Hasanah Card card holder is still very little.

\section{Research Purposes}

Based on the problem formulation that has been explained previously, the purpose of this study is to analyze the Corporate's Image and Advertising whether it has a positive and significant effect either partially or simultaneously on the Customer Decision to become a Hasanah Card Card Holder at BNI Syariah

\section{LITERATURE REVIEW Corporate Image}

Image is one of the factors that must be controlled by the company because it will greatly affect its business activities, both in marketing, sales or in establishing cooperation. The company's image is a view / impression, both of individuals or groups of these companies, if the image of the company does not seem good it will affect consumers not to buy products at the company. Some experts put forward a definition of the company's image.

According to Harrison (2005), a company's image is an impression, a feeling, a picture of the public towards a company; an impression intentionally created from an object, person or organization. According to Harrison in Mulyana (2009), complete information about the company's image includes the following four dimensions:

a. Personality
Overall characteristics of the company that are understood by the target public (public's knowledge about the company), such as trustworthy companies, companies that have social responsibility.

b. Reputation

Reputation is the public perception of organizational actions that have flowed and the prospects of the organization in the future, of course compared to similar organizations or competitors. Reputation is related to what the company has done and is believed to be the target public based on the experience of others and themselves.

c. Value

Values that are owned by a company in other words, corporate culture such as the attitude of management who cares about customers, employees who are quick to respond to requests and customer complaints.

d. Corporate identity

Components that facilitate the introduction of public targets for companies such as logos, colors and slogans.

Based on the understanding of some of the experts, it can be concluded that the company's image is an impression that reflects the public's view of a company.

\section{Advertising}

Advertising is a communication tool between producers and consumers. Advertising can be defined as a message offering a product aimed at consumers through the media. With advertising, producers will more easily convey messages to consumers. It can be said that advertising is one form of promotion in the company's strategy to market its business products to be known by the wider community and to increase sales so that the profits obtained will also be even greater. Some experts have defined advertising as a tool for companies to introduce their products. 
Wells, Burnett and Moriarty in Sutisna (2003), defines advertising as a form of non-personal communication paid by sponsors recognized by using mass media to persuade or influence viewers. According to Wells, Burnett and Moriarty (2006), there are four basic dimensions of advertising functions, namely:

a. Precipitation: creates awareness and stimulates needs and desires. Efforts to move the hearts of consumers from the state of hesitation to think about purchasing a brand or supporting ideas that may be real. This makes the creation of a general level of awareness in the recipient of the message.

b. Persuasion: encouraging action and creating promises. Efforts to move consumers at a level of purchase. This process takes minutes, hours, days, months or even a year, but it is the main goal of all advertising. By using attraction for basic emotions such as love, hate, fear, or the need for self-esteem, which seeks to develop actual sales.

c. Reinforcement: supports previous consumer decisions. Efforts to provide information that will lead to previous choices. Some information makes us feel good about our decision to buy a certain brand or not to buy another brand.

d. Reminder: create habits. Action as a trigger tool to create habitual brand behavior (Brand Loyalty) of experiences. Clearly, the advertising of the majority of consumers of industrial goods is of this type. The intention to keep the brand name fresh, there is no need to increase market share.

\section{Hasanah Card}

iB Hasanah Card is a financing card that functions as a credit card based on sharia principles, with a fixed, fair, transparent and competitive cost calculation system without interest calculation received in all MasterCard markers and all ATMs marked with CIRRUS throughout the world that are issued by BNI Syariah. Hasanah Card is divided into 3 types, Classic, Gold and Platinum. (Source: www.bnisyariah.co.id)

\section{Decision to become a Card Holder}

The decision to buy arises because of an objective assessment or emotional drive of the individual to choose whether or not to use the product. According to Kotler and Armstrong (2014), a purchasing decision is a stage of a decision process where consumers actually make a product purchase. Consumers as the main actors in the buying process are always a concern of producers.

Before the consumer decides to buy or use the product, there are stages or processes that are passed before the consumer finally decides to use the product. According to Kotler and Keller (2016), there are several stages or processes in making purchasing decisions, namely:

a. Decision of selected products

Consumers can make the decision to buy a product or service for another purpose, in this case the company must focus its attention on people who are interested in buying the products they offer.

b. Decision of the brand chosen Consumers must decide the brand of products and services to be purchased, because each product and service has its own differences.

c. Decision of the selected shop The consumer makes a decision about which supplier to use. Each consumer is different in terms of determining the supplier that can be due to location factors, low prices, complete product inventory, comfort, freedom of space, and so on

d. Decisions regarding amounts Consumers can make decisions about how many products or services to buy at a time. Purchasing may be more than one. 
e. Decision regarding the time of purchase chosen

Consumer decisions in timing can vary, for example there are those who visit every day, once a week, once a month, and maybe once a year.

f. Decision on how to pay

Consumers in purchasing a product or service must definitely make a payment. At the time of this payment there are usually consumers who make payments in cash.

\section{RESEARCH METHODS}

This type of research is associative research. Associative research is a research that aims to determine the relationship of two or more variables. The sampling method used is accidental sampling technique, by Slovin formula. Data collection method used in this research is Survey Method. Data were analyzed using multiple regression models.

\section{DISCUSSION}

\section{Classic assumption test (Normally Test)}

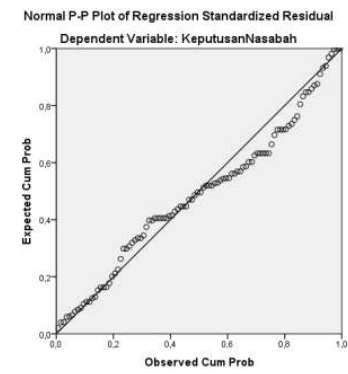

Figure 1 Normality Test Results Source: Attachment SPSS 24 processed 2019

Figure 1 above shows that the normality test is normally distributed. It can be seen that the line that represents the data actually follows the diagonal line. That the data distribution is said to be spread around a straight line (not scattered far from the straight line) so that the normality requirements can be met.

\section{Multiple Linear Regression Analysis}

Table 2 Results of Multiple Linear Regression Analysis

\begin{tabular}{|lc|c|c|}
\hline \multirow{2}{*}{ Model } & \multicolumn{2}{|c|}{ Unstandardized Coefficients } \\
\cline { 2 - 3 } & $B$ & Std. Error \\
\hline 1 & (Constant) & 6,082 & 2,426 \\
\hline
\end{tabular}

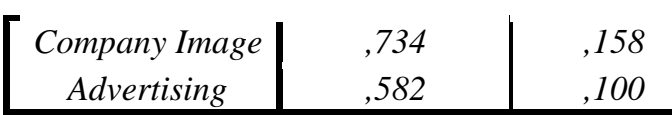

Source: Attachment SPSS 24 processed 2019

In Table 2 above, based on the results of the processing of multiple linear regression data regarding the company's image and advertising on the customer's decision to become a Hasanah Card BNI Syariah card holder, the regression equation is obtained as follows:

$Y=6.082+0,734 X_{1}+0,582 X_{2}$

From the linear regression equation above it can be concluded that:

a. The constant value indicates the value of the decision variable to become a card holder without the effect of corporate image and advertising variables. The equation shows a constant value of 6.082, meaning that the decision to become a Hasanah Card card holder without the effect of the company's image and advertising is 6.082, assuming other variables are controlled.

b. Regression coefficient of the corporate image variable of 0.734 states that the corporate image variable has a positive relationship with the customer's decision to become a Hasanah Card card holder. In addition, the coefficient value also indicates that if the corporate image variable increases by one unit, the customer's decision to become a Hasanah Card card holder will increase by 0.734 units assuming other variables remain.

c. The advertising variable regression coefficient of 0.582 states that the advertising variable has a positive relationship with the customer's decision to become a Hasanah Card card holder. In addition, the coefficient value also shows that if the advertising variable increases by one unit, the customer's decision to become an Hasanah Card card holder will increase by 0.582 units assuming the other variables remain. 


\section{Hypothesis testing}

Table 3 Partial Test (T Test)

\begin{tabular}{|l|l|l|l|}
\hline Variable & $\mathrm{T}$ & Sig. $\mathrm{t}$ & conclusion \\
\hline $\begin{array}{l}\text { Company } \\
\text { Image }\end{array}$ & 4,639 &, 000 & $\begin{array}{l}\text { Ha } \\
\text { accepted }\end{array}$ \\
\hline Advertising & 5,839 &, 000 & $\begin{array}{l}\text { Ha } \\
\text { Accepted }\end{array}$ \\
\hline
\end{tabular}

Source: Attachment SPSS 24 processed 2019

In Table 3, decision making is based on probability. If the significance value $<(\alpha=0.01) \mathrm{HO}$ is rejected and $\mathrm{Ha}$ is accepted, it means that there is an effect of variable $X$ on $Y$. If the significance value $>$ $(\alpha=0.01) \mathrm{HO}$ is accepted and $\mathrm{Ha}$ is rejected, it means that there is no effect of variable $X$ on $Y$

a. Partial test for corporate image variables based on the above calculation can be seen that the significant value of $t$ standard for corporate image variables is smaller than the significant value of $t$ arithmetic $0.000<0.01$ and the value of $t$ table is smaller than $t$ arithmetic 2.62747 <.639. Thus, it can be concluded that $\mathrm{HO}$ is rejected and $\mathrm{Ha}$ is accepted, which means that the company image variable has a positive and significant effect on the customer's decision to become a Hasanah Card card holder.

b. Partial test for advertising variables based on the above calculation can be seen that the significant value of $t$ standard for advertising variables is smaller than the significant value of $t$ arithmetic $0.000<0.01$ and the value of $t$ table is smaller than $t$ arithmetic $2.62747<5.839$. Thus, it can be concluded that $\mathrm{HO}$ is rejected and $\mathrm{Ha}$ is accepted, which means that the advertising variable has a positive and significant effect on the customer's decision to become a Hasanah Card card holder.
Table 4 Simultaneous Test (Test F)

\begin{tabular}{|c|c|c|c|c|c|}
\hline Model & $\begin{array}{c}\text { Sum of } \\
\text { Squares }\end{array}$ & Df & $\begin{array}{c}\text { Mean } \\
\text { Square }\end{array}$ & $F$ & Sig. \\
\hline $\begin{array}{c}\text { Regressi } \\
\text { on }\end{array}$ & 637,780 & 2 & 318,890 & 49,653 &, $000 b$ \\
Residual & 622,970 & 97 & 6,422 & & \\
Total & 1260,750 & 99 & & & \\
\hline
\end{tabular}

Source: Attachment SPSS 24 processed 2019

In Table 4 above with a 99\% confidence level $(\alpha=0.01)$ shows the company's image and advertising together or simultaneously have a significant effect on the customer's decision to become a Hasanah Card holder. This can be seen through the results of the F test, where the $F$ count $=49.653>F$ table 3.09 and the significance of $0.000<0.01$.

\section{Table 5 Determination Coefficient Test} (Adjusted R2)

\begin{tabular}{|c|c|c|c|c|}
\hline Model & $R$ & $\begin{array}{c}R \\
\text { Square }\end{array}$ & $\begin{array}{c}\text { Adjusted } \\
R \text { Square }\end{array}$ & $\begin{array}{c}\text { Std. Error of } \\
\text { the Estimate }\end{array}$ \\
\hline 1 &, $711^{a}$ &, 506 &, 496 & 2,534 \\
\hline
\end{tabular}

Source: Attachment SPSS 24 processed 2019

Based on Table 5 above, it can be seen the results of the coefficient of determination of the company's image and advertising variables on the customer's decision to become a Hasanah Card card holder ( $R$ Square) of 0.506. This value indicates that the magnitude of the effect of corporate image and advertising variables on customers' decision to become Hasanah Card holders is $50.6 \%$, while the remaining $49.4 \%$ (1 - 0.506) are other factors not examined in this study.

\section{CONCLUSION}

From the results of the analysis and discussion above, researchers can conclude about the effect of company image and advertising on Hasanah Card on the customer's decision to become a card holder at BNI Syariah Bank as follows: 
a. Corporate image, is known to have a positive and partially significant effect on customer decisions to become a Hasanah Card holder. This can be seen from the customer's assessment of BNI Syariah Bank because they have had good service. The customer agrees that BNI Syariah Bank has a good corporate image and service.

b. The advertising variable, is known to have a positive and partially significant effect on the customer's decision to become a Hasanah Card card holder, so it can be concluded that BNI Syariah Bank has made a good promotional strategy through advertising on social media to promote one of its products, the Hasanah Card. The customer agrees that after they see the Hasanah Card advertisement on social media such as television, youtube or brochures can be more convincing to them to become Hasanah Card holders.

c. Corporate image and advertising, it can be seen that both of these variables have a positive and significant effect simultaneously on the customer's decision to become a Hasanah Card holder. These variables contribute quite well, so it can be concluded that the company's image and advertising have a positive effect on the customer's decision to become an Hasanah Card holder and make customers more confident and easier to decide to become a Hasanah Card holder.

\section{Suggestion}

Based on the above conclusions, the authors submit a number of suggestions for consideration in improving the company's image and establishing better advertising promotion strategies for customers' decisions to become Hasanah Card holders at BNI Syariah Bank.

a. From the aspect of corporate image,

BNI Syariah Bank is already quite good, it is shown by the positive and significant effect given to the customer's decision to become a card holder. However, the reputation held by Bank BNI Syariah still does not adequately reflect a good corporate image. Therefore, BNI Syariah Bank should improve the company's reputation by one way to improve the structure of existing business activities by innovating with the times to continue to get awards such as the Brand Award held every year.

$b$. From the aspect of advertising, the promotion strategy through advertising is quite good and it is shown by the positive and significant effect that is given to the customer's decision to become a card holder. However, customers know products from BNI Syariah Bank such as Hasanah Card not through advertisements provided by the bank. Therefore, BNI Syariah Bank should optimize the frequency of ads appearing on social media both online and offline such as newspapers, magazines, radio, television, internet, and billboards and determine the right target market for Hasanah Card products.

c. In future studies, it is recommended to add independent variables or other indicators that can effect the customer's decision to become a Hasanah Card holder. This is intended to provide a broader picture of the problem being studied so as to provide better index results.

\section{Implications of Research Results}

Based on the suggestions above, the results of this study are expected to have managerial implications for BNI Syariah Bank as an additional reference in developing strategies to increase the number of Hasanah Card users. BNI Syariah already has a fairly good corporate image and promotion strategy in advertising. However, it is still necessary to reform the structure of business activities in carrying out other innovations so that they can keep up with the times so that BNI Syariah will not lose its reputation in the 
community and of course increase sales of its products. This can be done by one of them optimizing the frequency of promotion through advertising in online or offline media by determining the right target market.

\section{REFERENCE}

Ardianto, Elvinato, \& Soemirat S. (2007). Dasar-Dasar Public Relation. Bandung: Remaja Rosdakarya.

Ardy, D. A. (2013). Pengaruh Gaya Hidup, Fitur dan Harga Terhadap Keputusan Pembelian Blackberry Curve 9300. Surabaya: Universitas Negeri Surabaya.

Bilson, S. (2001). Memenangkan Pasar Dengan Pemasaran Efektif dan Profitable. Jakarta: PT. Gramedia Pustaka Utama.

Ekinci, Y., \& Hosany, S. (2006). Destination Personality; an Application of Brand Personality to Tourism Destinations. Journal of Travel Research, 127-140.

Ghozali, I. (2005). Aplikasi Analisis Multivariate dengan Program SPSS. Semarang: Badan Penerbit Universitas Diponegoro.

Ghozali, I. (2006). Aplikasi Analisis Multivariate dengan Program SPSS, Cetakan Keempat. Semarang: Badan Penerbit Universitas Diponegoro.

Ghozali, I. (2011). Aplikasi Analisis Multivariate dengan Program SPSS. Semarang: Badan Penerbit Universitas Diponegoro.

Hartanto, Y. I. (2012). Penerapapn produk Hasanah Card pada Bank Negara Indonesia Syariah Cabang Pekanbaru. Riau: Universitas Islam Negeri Sultan Syarif Kasim.

Hastuti, N. W. (2013). Pengaruh Bagi Hasil, Iklan, Pelayanan, Akad, Kepercayaan dan Citra terhadap Keputusan Nasabah Menabung Mudharabah. Yogyakarta: Universitas Islam Negeri Sunan Kalijaga.
Irawan, H. (2009). Analisis Faktor-Faktor yang Mempengaruhi Minat Nasabah dalam Memutuskan Menabung di Bank Syariah Mandiri Cabang Malang. Malang: Universitas Islam Negeri Bandung.

Istijanto. (2009). Aplikasi Praktis Riset Pemasaran. Jakarta: PT. Gramedia Pustaka Utama.

Kotler, P. (2000). Manajemen Pemasaran di Indonesia: Analisis Perencanaan Implementasi dan Pengendalian. Jakarta: Salemba Empat.

Kotler, P. (2011). Principles of Marketing. New Jersey: Prentice Hall International.

Kotler, P., \& Armstrong, G. (2008). Prinsip-Prinsip Pemasaran. Edisi 13 Jilid 1. Jakarta: Erlangga.

Kotler, P., \& Armstrong, G. (2012). Prinsip-Prinsip Pemasaran. Edisi 13 Jilid 2. Jakarta: Erlangga.

Kotler, P., \& Keller, K. L. (2012). Manajemen Pemasaran. Edisi Ketiga Belas. Jakarta: Erlangga.

Maisya, F. (2013). Pengaruh Peirklanan, Promosi Penjualan dan Hubungan Masyarakat terhadap Keputusan Menabung di PT. Bank Negara Indonesia Tbk. Cabang Bukit Tinggi. Padang: Universitas Negeri Padang.

Morrisan. (2010). Periklanan: Komunikasi Pemasaran Terpadi. Jakarta: Kencana.

Mulyana, D. (2009). Ilmu Komunikasi. Bandung: Remaja Rosdakarya.

Nachrowi, D. N., \& Hardius, U. (2008). Penggunaan Teknik Ekonometrika. Jakarta: Raja Grafindo Persada.

Peter, J. P., \& Jerry, C. O. (2000). Consumer Behavior: Perilaku Konsumen dan Strategi Pemasaran. Jakarta: Erlangga.

Poon, W. C. (2008). Users Adoption of EBanking Services: The Malaysian Perspective. Journal of Business and Industrial Marketing Vol. 23, 123. 
Priyatna, S. (2015). Dasar-Dasar Publik Relations. Bandung: Remaja Rosdakarya.

Rahmawati. (2008). Respon Nasabah Bank Danamon Syariah terhadap Dirham Card. Jakarta: UIN Syarif Hidayatullah Jakarta.

Rangkuti, F. (2003). Riset Pemasaran. Jakarta: PT. Gramedia Pustaka Utama.

Stanton, W. J. (2000). Prinsip Pemasaran. Jakarta: Erlangga.

Sukoco, E. (2013). Analisis Pengaruh Brand Image Sepatu Converse All Star terhadap Minat Beli Konsumen Pengguna Sepatu Converse All Star pada Mahasiswa Universitas Haluoleo Kendar. Kendar: Universitas Haluoleo.

Supranto, J. (2007). Teknik Sampling: untuk Survey \& Eksperimen. Jakarta: Rineka Cipta.

Supranto, J. (2011). Pengukuran Tingkat Kepuasaan Pelanggan. Jakarta: Rineka Cipta.

Umar, H. (2011). Metode Penelitian untuk Skripsi dan Tesis Bisnis. Jakarta: Raja Grafindo Persada.

Yusuf, M. (2013). Metode Penelitian Kuantitatif, Kualitatif, dan Peneltiian Gabungan. Edisi Pertama. Jakarta: Kencana. 
